\title{
Petrophysical Core-Based Zonation of An Oil Field In The Bredasdorp Basin South Africa
}

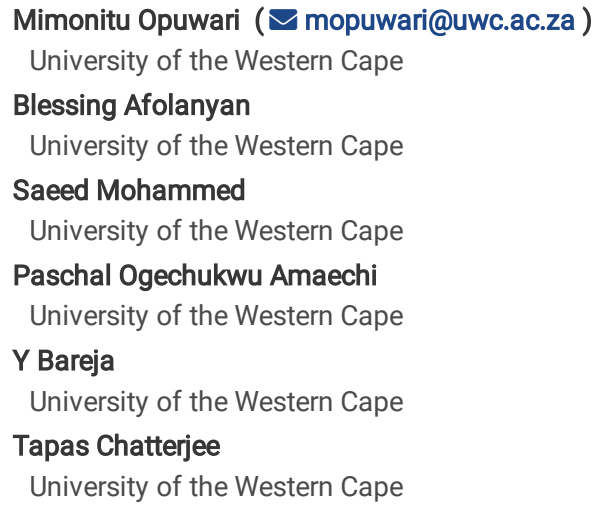

Research Article

Keywords: Lithofacies, Lucia's Classes, Flow Zones, Mineralogy, Oil field, South Africa

Posted Date: September 2nd, 2021

DOI: https://doi.org/10.21203/rs.3.rs-858196/v1

License: (c) (1) This work is licensed under a Creative Commons Attribution 4.0 International License. Read Full License 


\section{Abstract}

This study aims to generate rock units based on core permeability and porosity of an oil field in the Bredasdorp Basin offshore South Africa. In this study, we identified and classified lithofacies based on sedimentology reports in conjunction with well logs. Lucia's petrophysical classification method is used to classify rocks into three classes. Results revealed three lithofacies as A(sandstone, coarse to medium-grained), B (fine to medium-grained sandstone), and C (carbonaceous claystone, finely laminated with siltstone). Lithofacies $A$ is the best reservoir quality and corresponds to class 1 , while lithofacies $B$ and $C$ correspond to class 2 and 3, which are good and poor reservoir quality rock, respectively. An integrated reservoir zonation for the rocks is based on four different zonation methods (Flow Zone indicator (FZI), Winland r35, Hydraulic conductivity (HC), and Stratigraphy modified Lorenz plot (SMLP)). Four flow zones were identified as high(HFZ), moderate (MFZ), Low (LFZ), and tight (TFZ), respectively. The HFZ is the best reservoir quality composed of a megaporous rock unit, with an average FZI value between 5 to $10 \mu \mathrm{m}$, and $\mathrm{HC}$ from 40 to $120 \mathrm{mD} / \mathrm{v} 3$, ranked as very good. The most prolific flow units (HFZ and MFZ zones) form more than $75 \%$ of each well's flow capacities. The TFZ is the most reduced rock quality composed of impervious and nanoporous rock. There appears to be a slight increase of illite in the tight and low zones that block pore throats, thereby decreasing permeability. Therefore, illite has a dominant effect on flow zones. Quartz is the dominant framework grain, and siderite is the dominant cement that affects flow zones. This study has demonstrated a robust approach to delineate flow units in an oilfield. A novel sandstone reservoir zonation classification criteria developed from this study can be applied to other datasets of sandstone reservoirs with confidence.

\section{Introduction}

Petrophysical reservoir characterization on reservoir scale or classification of the pore spaces based on pore throat size distribution is a valuable tool in dividing pore types to explain uneven relationships between permeability and porosity for different rock types ${ }^{1,2}$. Porosity and permeability are the two properties that are important for reservoir rock typing or zonation studies, which can be measured directly from the core. Furthermore, the core analysis results in reservoirs produce valuable datasets regarded as the ground truth measurements used for the calibration and conditioning of other petrophysical measurements such as well logs and seismic ${ }^{3-7}$.

Many authors successfully apply core plug analysis results of porosity and permeability in carbonate and classic environments to quantify the reservoir flow and storage character and determine reservoir quality, e.g., ${ }^{8-13}$. An integrated petrophysical reservoir characterization method that involves core, well logs, and sedimentology helps to improve reservoir description by investigating various rock types that ultimately leads to an enhanced oil recovery ${ }^{14-17}$. Several studies $^{18-23}$ have reported that reservoir quality is controlled by the pore geometry, which determines fluid movements. The changes from diagenetic processes could alter permeability, porosity, and lithology within a reservoir that would produce zones with different reservoir properties. Therefore, reservoir rock type classification or zonation and modelling is an essential method to explore in the oil field development stage to investigate factors that influence variations in reservoir properties.

The oil field investigated in this study is situated in the Bredasdorp Basin, which lies offshore on the southern flank of South Africa. The Bredasdorp Basin holds a promising hydrocarbon prospect with several exploration, development, appraisal, and production wells drilled over the years. The Lower Cretaceous age sediments have been of primary exploration interest with renewed emphasis due to the recent hydrocarbon discoveries in commercial quantities in the southern Outeniqua basin offshore, South Africa.

Despite the previous studies conducted on flow zonation in the Bredasdorp Basin ${ }^{24-26}$ for the western, central, and northwestern parts of the Bredasdorp Basin, all the studies are targeted at the gas field in the Bredasdorp Basin. Based on our knowledge, there is no published work regarding reservoir rock typing or flow zonation of an oil field in the Bredasdorp Basin. Consequently, this work is focused on this important but neglected field. In this study, we identified and classified lithofacies based on sedimentology reports in conjunction with well logs. We used Lucia's Petrophysical classification method to produce three different classes of rock. An integrated reservoir zonation for the rocks is based on four different zonation methods (Flow Zone indicator (FZI), Winland r35, Hydraulic conductivity $(\mathrm{HC})$, and Stratigraphy modified Lorenz plot (SMLP). In addition, quantitative mineralogy results from two wells are introduced to establish the effects of mineralogy on flow zones.

\section{Geological Overview}

The Bredasdorp sub-basin is a passive marginal sub-basin (associated with syn-rift half-graben) located beneath the Indian Ocean, covering approximately $18,000 \mathrm{~km}^{2}$. It is arguably one of the largest producing hydrocarbon Basins within Southern Africa $27-30$

The study is located in the Bredasdorp Basin, part of the larger Outeniqua sub-basin off South Africa's south coast (Fig. 1). The Bredasdorp basin has been extensively explored and is well-known for its hydrocarbon potential. The majority of South Africa's hydrocarbon discoveries and prospects have been identified in the Bredasdorp Basin. The basin is bounded on the north-eastern part by the Infanta Arch, while the Columbine-Algulhas Arch is on the western and southwestern sides ${ }^{31,32}$. Four wells (OW1, OW2, OW3, and OW4) are used in this study, indicated by the red text in Fig. 1.

The stratigraphic nomenclature of sedimentary successions for South Africa's Offshore Basins is well documented. The sequences were numbered from 1 to 22 and alphabets based on major unconformities identified on seismic Sect. ${ }^{29,33}$ (Fig. 2).

According to ${ }^{30}$, Bredasdorp Basin sediments were derived from the erosion of the Cape Supergroup and Karoo Supergroup's sandstones and shales. The Cape supergroup sediments are made up of sequences from shallow marine, transitional, and deep-sea environments. During the Cape orogeny, the Cape supergroup was folded, generating the Cape fold belt, which extended offshore and on the coast of South Africa ${ }^{34}$. The Karoo supergroup was deposited atop a retro arc foreland basin when subduction and erosion began $29,35-37$. From the late Carboniferous through the early Jurassic period, the Karoo supergroup 
consisted of glacial, alluvial deltaic, and marine deposits ${ }^{38}$. There was evidence of rifting on Eastern Gondwana after the erosion of the Karoo supergroup, and syn-rift half grabens appeared ${ }^{30}$.

Mature shale deposited in the deep marine within the Mid-Aptian age of 13At1 in the drift section serves as the oil field's primary source rock (Fig. 2).

There are two major reservoirs in the Bredasdorp Basin. These reservoirs are shelf sandstones (syn-rift section) and deep marine turbidite sandstones (drift section $)^{32}$. The wells in the study area encountered deep marine turbidite sandstones. The drift marine shales operate as the significant seals in the Bredasdorp basin. The seal at the Syn-rift section is non-connecting faults in tilted form and faulted blocks. Both structural and stratigraphic traps are present in the Bredasdorp Basin. Tilted fault blocks are common structural traps in the syn-rift section, while stratigraphic traps are widespread within the drift Section ${ }^{32,37}$.

\section{Material And Method}

There are four wells available in the oilfield used for this study. Two cores were cut in well (OW1), with a total of $33.24 \mathrm{~m}$ were recovered. The core consists of deep marine sandstone with claystone at the base. Two cores were cut in well (OW2) with a $25.01 \mathrm{~m}$ recovery, while three cores were cut in well (OW3) with a total recovery of $28.42 \mathrm{~m}$, comprise mainly sandstone with occasional thin claystone interbed. Finally, three cores were cut back to back in well (OW4) with a total recovery of $32.04 \mathrm{~m}$. Core analyses, including helium porosity, vertical and horizontal permeability, and grain density, were conducted at 800 psi confining pressure on 371 core plugs that produced the porosity and permeability data used for this study.

Conventional core analysis data (Porosity and Permeability) for all wells and mineralogical data were available for two wells (OW2 and OW4). In addition, conventional well logs (gamma-ray, resistivity, density, and sonic) were available for all the wells. The evaluation process commences with the classification of lithofacies through to the delineation of reservoir zones.

In conjunction with the machine learning rock typing approach using well logs and Lucia's Petrophysical rock classification models, the Sedimentology report was adopted to group reservoir rocks into three distinct lithofacies. Four different petrophysical rock typing methods (Hydraulic conductivity(HC), Winland r35 pore throat radius Petrophysical Rock Type (PRT), Flow Zone Indicator (FZI), and Stratigraphy Modified Lorenz Plot (SMLP) applied for grouping of reservoir rocks into flow zones. Explanation of the methods is discussed in the result section.

\section{Results And Discussion}

\subsubsection{Lithofacies and Lucia's Petrophysical Classification}

\subsubsection{Lithofacies}

The sedimentology report indicates that the wells' sandstone reservoirs s are compositionally and texturally homogeneous; therefore, lithofacies classification is possible. The sandstones are predominantly clean, very fine to coarse-grained, variably sorted, slightly lithic, and very slightly carbonaceous ${ }^{32}$. Porosity reduction is influenced by quartz overgrowth, with a minor amount of calcite infilling. The sandstones are occasionally silty.

The rock types classification into lithofacies was achieved by integrating well logs (gamma-ray, resistivity, and density) and sedimentology reports. The sediments of the studied wells are mainly of deep marine depositional environment. Therefore, a detailed core description of the sediments was obtained from sedimentology reports and previous work in the studied wells that provided a geological classification framework based on texture and grain size. As a result, three lithofacies were identified and subsequently grouped as lithofacies $A, B$, and C from core description and sedimentology reports. Lithofacies $A$ is a clean, massive channel sandstone, coarse to medium grains; lithofacies B is fine to medium grains sandstone interbedded in places with siltstone, moderately sorted. On the other hand, lithofacies $\mathrm{C}$ is carbonaceous claystone, finely laminated with siltstone ${ }^{32}$.

A machine learning rock classification algorithm using well logs (gamma-ray, density, and resistivity) from IP.4.7 rock typing module was introduced in this study to group reservoir rocks into various clusters and integrate results with core defined lithofacies. According to ${ }^{39}$, clustering is the method and algorithm used to cluster or group data according to measured or perceived characteristics and similarity ${ }^{40}$. The results from cluster analysis for rock types are shown in Table 1 and (Fig. 3).

Table 1

Results of rock classification, clustering lithofacies into three groups

\begin{tabular}{|lllll|}
\hline Lithofacies & \# points & GR & Resistivity & Density \\
& & Mean Standard deviation & Mean Standard deviation & \begin{tabular}{l} 
Mean Standard deviation \\
\hline A
\end{tabular} \\
\hline B & 444 & 23.98 .5 & 22.410 .3 & 2.370 .03 \\
\hline C & 72 & 31.317 .4 & 6.511 .3 & 2.380 .03 \\
\hline
\end{tabular}

Furthermore, we integrated the results of the rock clustering method with sedimentology to consolidate lithofacies rock classification as follows:

Lithofacies A: Lithofacies A is a massive sandstone, coarse to medium grains with an average gamma-ray value of $24 \mathrm{API}$, resistivity of 22 ohmm, and density of $2.37 \mathrm{~g} / \mathrm{cc}$. 
Lithofacies B: Represents fine to medium grains sandstone interbedded in places with siltstone, moderately sorted with an average gamma-ray value of 31 $\mathrm{API}$, resistivity of $7 \mathrm{ohmm}$, and density of $2.38 \mathrm{~g} / \mathrm{cc}$.

Lithofacies C: Carbonaceous claystone, finely laminated with siltstone with an average gamma-ray value of 75 API, resistivity of 1.5 ohmm, and density of $2.58 \mathrm{~g} / \mathrm{cc}$.

Lithofacies $\mathrm{A}$ is ranked as the best reservoir rock, followed by lithofacies $\mathrm{B}$ and $\mathrm{C}$, respectively.

\subsubsection{Lucia's Petrophysical Classification}

To determine the rock type in a reservoir, it is essential to understand the primary rock properties, such as the mineralogy, texture, grain packing, and other parameters because they influence the petrophysical properties of rocks $10,12,13,17,41,42$. Lucia's Petrophysical rock classification is a technique used to relate pore size distribution to rock fabric with laboratory measurements of porosity and permeability ${ }^{43}$. Lucia's classification method has been successfully applied to carbonate rocks in which the pores are categorized into two broad categories: interparticle and vuggy. Rocks with interparticle pore spaces comprise three rock classes grouped as class 1,2 , and 3.the grouping of the rocks is based on texture,mud-dominated or grain-dominated 44 .

Though Lucia's Petrophysical classification method is mainly applied to carbonate rocks, we attempted this method in this study to classify the rock types and also to establish the relationship between our data with the standard Lucia's classification by superimposing our data on the standard Lucia's classification model developed in the Interactive Petrophysics software package, IP.47. The results show that our data mostly clustered around class 1 (grainstone with permeability ranging from $50 \mathrm{mD}$ to $1000 \mathrm{mD}$, and porosity from $15 \%$ to $22 \%$ ), followed by class 2 (grain-dominated packstones with permeability ranging from $1 \mathrm{mD}$ to $50 \mathrm{mD}$ and porosity from $12-18 \%$ ) and class 3 (mud - dominated fabric with a permeability of $\leq 1 \mathrm{mD}$ and porosity from $7-12 \%$ ) presented in Fig. 4.

Generally, the best reservoir quality rock belongs to class 1 sandstone with very good permeability and porosity. On the other hand, the least reservoir quality rock belongs to class 3 , which is mud-dominated with low permeability and fair porosity.

\subsection{RESERVOIR ROCK TYPE CLASSIFICATION}

\subsubsection{Hydraulic Flow Unit}

The concept of the hydraulic flow unit was initially proposed from the Kozeny-Carmen equation of a capillary tube model for rock pore spaces, with a key parameter in the method as the reservoir quality index (RQI), which is the average hydraulic radius in a rock ${ }^{45-48}$. The input parameters for reservoir quality index (RQI) and flow Zone indicator (FZI) are core porosity (Phi) and permeability (K) data that present the relationship below:

Rock quality index $(\mathrm{RQI})=0.0314 \times$ Sqrt $(\mathrm{K} / \mathrm{Phi})$

Pore-Grain volume ratio $(\mathrm{PhiZ})=\mathrm{Phi} /(1-\mathrm{Phi})$

Flow Zone Indicator $(\mathrm{FZI})=\mathrm{RQI} / \mathrm{PhiZ}$

From a log-log plot of RQI against PhiZ, we can determine points of similar FZI characteristics of value because they plot on a similar line with identical flow characteristics and identify flow zone boundaries. Therefore, we first select flow unit boundaries based on points positioned on $45^{0}$ lines with similar FZI values in the analysis. Then, we create hydraulic flow units using the FZI boundaries. This method has been successfully applied and documented by researchers in carbonate and clastic reservoirs ${ }^{9,24,49}$.

Results present five flow units vertical boundary lines shown in the histogram of Fig. $5 \mathrm{a}$, and the flow units are calculated using the boundaries set in the flow units statistical table 2, which resulted in five hydraulic flow units HFU1, HFU2, HFU3, HFU4, and HFU5 shown in Fig 5b. The boundaries using FZI indicate that HFU1 range from 0 to 1 micron, HFU 2 from 1 to 2 microns, HFU3 from 2 to 3 microns, and HFU 4 from 3 to 5 HFU 5 from 5 to 10 microns. HFU 5 presents the best reservoir rock quality with RQI ranging from 0.5 to 2.1 microns, and the least reservoir rock flow unit is HFU with an RQI value ranging from 0.02 to 0.2 microns.

\subsubsection{Winland r35 Rock Typing Model}

Winland (1972) ${ }^{50}$ created a method for determining pore throat radius from core data using core measurements of porosity and permeability data, published by ${ }^{51}$. From the Winland $\mathrm{r} 35$ method,the pore throat radius ( $\left.\mathrm{r} 35\right)$, corresponding to the 35 th percentile of mercury saturation ( $\mu \mathrm{m}$ ) could be calculated on different data such as well logs and core provided they have porosity and permeability data ${ }^{15,51,52}$. From that concept, Winland noted that large pores connected large crystals, and small pores connected small crystals. Therefore, Winland indicated that if the intercrystalline pore system is filled by intergranular and solution pore, the one that controls outflow and inflow into large pore is the smallest pore system ${ }^{53}$. Winland's correlation equation between pore sizes, porosity, and permeability published by ${ }^{51}$ is shown in Eq. 4.

Winland $r 35=\log (0.732+0.588 \log (K)-0.864 \log (P h i))$

Where Phi is porosity (\%) and $\mathrm{K}$ is air permeability in $\mathrm{mD}$. From Eq. 4, rock typing can be done by calculating the r35 value for each sample, classifying the sample with the same 35 value, and making an iso-pore throat line in a graph. In this study, rock typing has been done for 371 plug samples from routine core analysis with Winland r35 method. Our result was superimposed on the standard Winland r35 plot shown in Fig. 6a. From the plot, we obtained distribution 
pore spaces, porosity, and permeability at iso-pore throat line that presents five hydraulic flow units (HFU5 as mega pores ranging between 10 to $20 \mu \mathrm{m}$, HFU4 as macropores between 4 to $10 \mu \mathrm{m}$, HFU3 as mesopore between 2 to $4 \mu \mathrm{m}$, HFU2 as micropores ranges between 1 to $2 \mu \mathrm{m}$, and HFU1 as nanopores less than $1 \mu \mathrm{m}$ ). The porosity/permeability function (K/Phi) was also introduced in e Fig. $6 \mathrm{~b}$ to understand better the influence of porosity and permeability on pore throat size distribution and connectivity. Applying the (K/Phi) plot indicates that higher reservoir quality is assigned to the mega pore rocks, whereas the lowest is assigned to the nanopore rocks (Fig. 6b). Though the plot may successfully group the rocks, the influence of diagenesis and the lithology must be considered $20,54,55$. Several empirical relationships were established from the Winland $r 35$ pore throat method to estimate permeability from porosity.

\subsubsection{Hydraulic Conductivity (HFU) Method}

From HFU and in reference to ${ }^{56}$, reservoir quality index method, the hydraulic conductivity method was developed ${ }^{57}$ for sandstone reservoirs. This method was applied in this study because we are working on sandstone reservoirs. The technique was developed by 58 to obtain a capillary model for a porous medium from the relationship between permeability and porosity from Eq. 6: In this study, the method developed by Scheidegger, 1957 was modified and called hydraulic reservoir unit (HRU) to replace conductivity that best fits the purpose of the study.

Hydraulic Reservoir Unit $(H R U)=\left\{\right.$ Permeability/ $\left(1014^{\star}\right.$ (Porosity) $\left.\left.{ }^{\wedge} 3\right)\right\} * 0.1 \ldots$

In applying the hydraulic conductivity method, we first calculate HRU from each core sample using Eq. 5, then cross plot of hydraulic conductivity against (Permeability/Porosity) $)^{0.5}$ and establish five different HRU's (Fig. 7). HRU5 ranges from 50 to 120; HRU4 from 20 to 50; HFU3 from 5 to 20; HRU2 from 1 to 5; and HRU1 less than 1. The best reservoir quality is HRU5, and the least reservoir rock quality is HRU1. An empirical power relation was established to estimate hydraulic conductivity as follows:

Hydraulic Conductivity $=0.56$ * $\log \left((\text { Permeability/Porosity })^{0.5}\right)^{\wedge} 2.39 \mathrm{R}^{2}=0.91 \ldots .(6)$

\subsubsection{SMLP Method}

Stratigraphic Modified Lorenz Plot (SMLP), a petrophysical-based method, was also used in this study to identify hydraulic flow units within a sequencestratigraphic framework ${ }^{59-61}$. This method is applied through analysis of porosity and permeability to establish the vertical variation of flow (permeability with the thickness, kh) and storage capacity (porosity with the thickness, Ph). The SMLP utilizes the cross plot of cumulative flow and storage capacity values to determine flow units within a stratigraphic framework from base to top of reservoir ${ }^{61,62}$. Significant inflection points on the SMLP are interpreted to represent changes in flow and storage capacity flow unit. The interval of cumulative flow and storage capacity that slopes higher than $45^{0}$ lines on the plot is used to indicate high flow and low storage capacity; interval with a slope lower than the $45^{0}$ lines on the plot represents higher storage and low flow capacity, while those that plot around the $45^{\circ}$ lines represents an interval of equal flow and storage capacity.

SMLP was generated for our study using porosity and permeability values (Fig. 8). According to SMLP, four flow units (FU1 to FU4) are recognized in well OW1(red line), OW2 (black line), OW3 (green line), and five flow units (FU1 to FU5) are recognized for well OW4 (blue line) respectively. As seen in Fig. 8, FU1 presents the best reservoir quality with a high flow unit in all the wells, whereas FU2 represents the least reservoir quality and poor flow unit which are a barrier to flow.

\subsection{Reservoir Zonation Model}

Integrating the lithofacies, Lucia's Petrophysical rock classification model with different reservoir characterization methods developed culminated into a new applicable reservoir zonation scheme for the oil field presented in Table 2. We used an average value of the different reservoir zonation methods to produce four distinct flow zones as high flow zone (HFZ), moderate flow zone (MFZ), low flow zone (LFZ), and tight flow zone (TFZ), respectively. The HFZ porosity and permeability values range from $18-22 \%$ and permeability from $200 \mathrm{mD}$ to $1000 \mathrm{mD}$, with Winand r35 values $\geq \mathrm{I0} \mu \mathrm{m}$; FZI between 5 to $10 \mu \mathrm{m}$, HC between 50 to 120 , which corresponds to HFU5, where the highest and the best reservoir quality is detected. Therefore, it is ranked as very good (Table 2 ). MFZ porosity and permeability values range from $12 \%$ to $18 \%$ and permeability from $50 \mathrm{mD}$ to $200 \mathrm{mD}$, with Winand r35 values ranging from 4 to I0 $\mu \mathrm{m}$; FZI between 3 to 5 $\mu \mathrm{m}, \mathrm{HC}$ between 20 to 50 , which corresponds to HFU4, ranked as good reservoir quality. LFZ porosity and permeability values range from $14 \%$ to $18 \%$ and permeability from $10 \mathrm{mD}$ to $50 \mathrm{mD}$, with Winand r35 values ranging from 2 to $4 \mu \mathrm{m}$; FZI between 2 to $3 \mu \mathrm{m}$, HC between 5 to 20 , which corresponds to HFU3, ranked as fair reservoir quality. TFZ is classified as an impervious reservoir rock with porosity and permeability values less than $10 \%$ and $1.0 \mathrm{mD}$, respectively. Winand $\mathrm{r} 35, \mathrm{FZI}$, and $\mathrm{HC}$ values are $\leq 1 \mu \mathrm{m}$ for TFZ, which corresponds to HFU1, with the least reservoir quality. We observed permeability variations at similar porosities in some flow zones, attributed to pore type control on fluid flow. It has been reported previously that sandstone samples with similar porosities can have different permeability resulting from the impact of diagenetic overprints on the pore throat radius of sandstones ${ }^{63,64}$. Consequently, we used quantitative point-count mineralogy results of well OW3 and OW4 (Table 3) to determine mineral types and abundances in different zones that affect reservoir quality, resulting in diagenetic effects on the pore throat radius.

The results indicated quartz as the dominant framework grain ranging in abundance from $62 \%$ to 82 weight \% (Table 3 ). Feldspar, lithics, and glauconite were all identified in varying proportions in the studied samples. According to ${ }^{65,66}$, the main factors that influence the permeability and porosity of sandstone reservoirs are the clay type and distribution, cementation, sandstone composition, hydrocarbon saturation, and compaction. Quartz overgrowth and siderite are the predominant types of cement in the samples ranging from $7.9 \%$ to $18.8 \%$ and $0.9 \%$ to 6.2 weight $\%$, respectively. Dolomite is variable and minor pyrite is present in some samples as an alteration and replacement product. Samples of high siderite content $\geq 2 \%$ belong to the tight flow zone, while samples with low siderite content $\leq 2 \%$ belong to the low, moderate, and high flow zones. The most abundant clay mineral is the kaolinite ranging from $1 \%$ to $4.1 \%$, and illite ranging from traces to $2.6 \%$. The amount of cement (siderite) and clay minerals (kaolinite and illite) increases in the tight flow zone compared to other zones. Due to the coarse nature of kaolinite and its position on the pore spaces and not in the pore throat, kaolinite is less destructive of permeability than other clay minerals ${ }^{65,67}$. However, there appears to be a slight increase of illite, which could affect permeability. This may be attributed to why illite correlates better with 
the flow zones, where samples with illite of $2 \%$ to $2.6 \%$ belong to the tight flow zones, $1.3 \%$ belong to the low flow zone, and moderate and high flow zones have illite $\leq 0.7 \%$.

The results of integrating the four different methods (FZI, Winland r35, HC, SMLP) with lithofacies alongside each other are presented in Figures 9 to 12 for each well. In addition, detailed analyses of all rock types in a zone are described in the following sections.

Table 2

Calculated average values of petrophysical parameters and ranges used to group rock types into five petrophysical categories modified after ${ }^{26}$

\begin{tabular}{|c|c|c|c|c|c|c|c|c|c|c|c|c|}
\hline \multirow[t]{6}{*}{ Well } & \multirow[t]{6}{*}{$\begin{array}{l}\text { Top } \\
\text { Depth } \\
\text { (m) }\end{array}$} & \multirow[t]{6}{*}{$\begin{array}{l}\text { Bottom } \\
\text { Depth } \\
\text { (m) }\end{array}$} & \multirow[t]{6}{*}{$\begin{array}{l}\text { Thickness } \\
\text { (m) }\end{array}$} & \multirow{2}{*}{$\begin{array}{l}\text { Porosity } \\
\% \\
18-22\end{array}$} & \multirow{2}{*}{$\begin{array}{l}\text { Permeability } \\
\text { mD } \\
200-1000\end{array}$} & \multirow{2}{*}{$\begin{array}{l}\text { Zone/ } \\
\text { Unit } \\
\text { High }\end{array}$} & \multirow{2}{*}{$\begin{array}{l}\text { r35 } \\
(\mu \mathrm{m})\end{array}$} & \multirow{2}{*}{$\begin{array}{l}\text { HFU } \\
\\
5\end{array}$} & \multirow{2}{*}{$\begin{array}{l}\text { Rock Type } \\
\text { Megaporous }\end{array}$} & \multirow{2}{*}{$\begin{array}{l}\text { FZI } \\
(\mu \mathrm{m})\end{array}$} & \multirow{2}{*}{$\begin{array}{l}\text { Ranking } \\
\text { Very Good }\end{array}$} & \multirow{2}{*}{$\begin{array}{l}\text { Hydraulic } \\
\text { Conductivity } \\
\text { mD/v3 } \\
50-120\end{array}$} \\
\hline & & & & & & & & & & & & \\
\hline & & & & $12-18$ & $50-200$ & Moderate & $4-10$ & 4 & Macroporous & $3-5$ & Good & $20-50$ \\
\hline & & & & $10-18$ & $10-50$ & Low & $2-4$ & 3 & Mesoporous & $2-3$ & Fair & $5-20$ \\
\hline & & & & $10-14$ & $1-10$ & Very Low & $1-2$ & 2 & Microporous & $1-2$ & Poor & $1-5$ \\
\hline & & & & $<10$ & $<1.0$ & Tight & $<1$ & 1 & Nanoporous & $<1$ & Impervious & $\leq 1$ \\
\hline \multirow[t]{5}{*}{ EB1 } & 2624.0 & 2634.7 & 10.7 & 17.7 & 332.0 & High & 14.0 & 5 & Megaporous & 6.4 & Very Good & 62.3 \\
\hline & 2634.7 & 2635.8 & 1.1 & 11.3 & 10.0 & Low & 2.3 & 3 & Mesoporous & 2.1 & Fair & 6.0 \\
\hline & 2635.8 & 2640.0 & 4.2 & 15.8 & 216.0 & High & 13.1 & 5 & Megaporous & 6.5 & Very Good & 66.6 \\
\hline & 2640.0 & 2648.7 & 8.7 & 15.5 & 104.4 & Moderate & 8.0 & 4 & Macroporous & 4.5 & Good & 30.0 \\
\hline & 2648.7 & 2652.2 & 3.5 & 15.0 & 60.0 & Moderate & 6.9 & 4 & Macroporous & 3.9 & Good & 26.0 \\
\hline \multirow[t]{2}{*}{ EB2 } & 2579.4 & 2584.4 & 5.0 & 18.1 & 333.0 & High & 14.7 & 5 & Megaporous & 6.4 & Very Good & 66.5 \\
\hline & 2584.4 & 2589.0 & 4.6 & 17.8 & 245.0 & High & 12.4 & 5 & Megaporous & 5.6 & Very Good & 51.0 \\
\hline \multirow[t]{6}{*}{ EB3 } & 2589.0 & 2596.1 & 7.1 & 16.7 & 164.0 & Moderate & 9.6 & 4 & Macroporous & 4.7 & Good & 35.7 \\
\hline & 2616.6 & 2620.5 & 3.9 & 16.2 & 275.0 & High & 14.6 & 5 & Megaporous & 7.5 & Very Good & 64.7 \\
\hline & 2620.5 & 2622.7 & 2.2 & 7.0 & 0.4 & Tight & 0.8 & 1 & Nanoporous & 0.8 & Impervious & 1.0 \\
\hline & 2622.7 & 2636.5 & 13.8 & 17.1 & 304.0 & High & 14.0 & 5 & Megaporous & 6.4 & Very Good & 70.0 \\
\hline & 2636.0 & 2637.3 & 1.3 & 6.4 & 0.9 & Tight & 0.9 & 1 & Nanooporous & 1.1 & Impervious & 1.2 \\
\hline & 2637.3 & 2642.5 & 5.2 & 16.7 & 110.0 & Moderate & 8.3 & 4 & Macroporous & 4.2 & Good & 31.0 \\
\hline \multirow[t]{7}{*}{ EB4 } & 2609.4 & 2612.6 & 3.2 & 17.7 & 221.0 & High & 11.5 & 5 & Megaporous & 5.3 & Very Good & 49.5 \\
\hline & 2612.6 & 2616.4 & 3.8 & 17.7 & 167.0 & Moderate & 10.1 & 4 & Macroporous & 4.7 & Good & 39.5 \\
\hline & 2616.4 & 2618.0 & 1.6 & 7.2 & 0.3 & Tight & 0.4 & 1 & Nanoporous & 0.5 & Impervious & 0.3 \\
\hline & 2618.0 & 2619.8 & 1.8 & 10.2 & 10.0 & Low & 3.5 & 3 & Mesoporous & 2.4 & Fair & 14.2 \\
\hline & 2619.8 & 2623.0 & 3.2 & 4.2 & 0.2 & Tight & 0.5 & 1 & Nanoporous & 0.9 & Impervious & 0.7 \\
\hline & 2623.0 & 2630.0 & 7.0 & 15.8 & 109.0 & Moderate & 4.7 & 4 & Macroporous & 3.2 & Good & 22.0 \\
\hline & 2630.0 & 2642.0 & 12.0 & 16.6 & 123.0 & Moderate & 6.9 & 4 & Macroporous & 3.6 & Good & 23.4 \\
\hline
\end{tabular}


Table 3

Result of quantitative mineralogical analysis of wells OW3 and OW4 indicating the dominant cement and clay that affects flow zones

\begin{tabular}{|c|c|c|c|c|c|c|c|c|c|c|c|c|}
\hline \multirow[b]{2}{*}{ Well } & \multirow[b]{2}{*}{ Zone } & \multirow[b]{2}{*}{ Sample } & \multicolumn{5}{|c|}{ Framework Grain } & \multicolumn{4}{|l|}{ Cements } & \multirow{2}{*}{$\begin{array}{l}\text { Clay } \\
\text { Kaolinite }\end{array}$} \\
\hline & & & Quartz & Feldspar & Lithics & Glauconite & Carbonaceous & Quartz & Dolomite & Siderite & Pyrite & \\
\hline & & Depth & $\%$ & $\%$ & $\%$ & $\%$ & $\%$ & Overgrowth & $\%$ & $\%$ & $\%$ & $\%$ \\
\hline & & $\mathrm{m}$ & & & & & & $\%$ & & & & \\
\hline ow3 & High & 2613.0 & 79.8 & 3.0 & 3.1 & 1.3 & - & 7.9 & - & 1.3 & - & 1.6 \\
\hline oW3 & High & 2620.2 & 80.2 & 2.0 & 2.5 & 0.3 & - & 11.4 & - & 1.0 & - & 1.8 \\
\hline oW3 & Moderate & 2625.7 & 80.4 & 2.0 & 1.5 & 1.0 & - & 10.9 & - & 1.4 & 0.5 & 2.0 \\
\hline ow3 & Moderate & 2634.8 & 76.6 & 2.5 & 2.0 & 1.7 & - & 12.1 & - & 0.7 & & 2.5 \\
\hline OW4 & High & 2615.4 & 79.8 & 2.3 & 2.8 & 1.8 & traces & 10.6 & 1 & 1 & 0.5 & traces \\
\hline OW4 & Moderate & 2615.7 & 79.7 & 2.9 & 6.2 & 1.3 & traces & 7.9 & 0.3 & 0.3 & & 1.3 \\
\hline OW4 & Moderate & 2616 & 77.1 & 3 & 3 & 2 & 0.3 & 10.3 & 1 & 1 & 0.5 & 1 \\
\hline OW4 & Tight & 2617.3 & 62.4 & 3.2 & 1.1 & 2.2 & 5.8 & 18.8 & 1.1 & 6.2 & 2.6 & 4.1 \\
\hline OW4 & Tight & 2622.7 & 64.1 & 3.7 & 3.5 & 1 & 1.3 & 17.1 & 0.9 & 2.2 & 0.4 & 1.7 \\
\hline OW4 & Low & 2624.9 & 72.1 & 0.8 & 3 & 1 & 1 & 16.8 & 0.5 & 1.8 & 0.3 & 1.5 \\
\hline OW4 & Low & 2625.4 & 76.5 & 0.9 & 2.3 & & 1.2 & 14.9 & 0.7 & 0.9 & 0.5 & 1.4 \\
\hline OW4 & Moderate & 2641.8 & 82 & 2.4 & 0.5 & & & 14.6 & 0.5 & - & - & traces \\
\hline
\end{tabular}

\subsubsection{HFZ}

The rocks are mainly coarse-grained sandstone (lithofacies A), and samples are, on average, moderately to poorly sorted and belong to class 1 of Lucia's Petrophysical classification. The HFZ's have very good petrophysical properties with porosity and permeability ranging from $18-22 \%$ and $200 \mathrm{mD}$ to $1000 \mathrm{mD}$, respectively (Table 2). The pore throat size is the best, with Winland r 35 greater than $10 \mu \mathrm{m}$ and $\mathrm{FZI}$ in the range between 5 to $10 \mu \mathrm{m}$, and $\mathrm{HC}$ between 50 to $120 \mathrm{mD} / \mathrm{v} 3$. The HFZ is composed of HFU5 and ranked as a very good reservoir quality rock. The HFZ appears at the upper part of the reservoirs in the studied wells (Fig. 9 to 12) track 2. The content of framework grain is high ( $80 \%$ on average), and the average content of quartz overgrowth is (10\%), and siderite cement $(\leq 1.3 \%)$ and illite clay mineral $(\leq 0.5 \%)$ are low (Table 3$)$. Seven HFZ's are identified in the wells. The best HFZ is found in well OW1(Fig. 9$)$ with a thickness of $10 \mathrm{~m}$ and has strong flow capacity, FU1 (60\%), and storage capacity of $42 \%$.

\subsubsection{MFZ}

The rocks are generally composed of lithofacies A (coarse-grained sandstone) and B (fine to medium-grained sandstone) and belong to classes 1 and 2 of Lucia's Petrophysical classification. The MFZ's have good petrophysical properties with porosity ranging from $12-18 \%$ and permeability from $50 \mathrm{mD}$ to $200 \mathrm{mD}$, respectively (Table 2). The pore throat size is good with calculated Winland r 35 values range between 4 to $10 \mu \mathrm{m}$, $\mathrm{FZI}$ in the range between 3 to $5 \mu \mathrm{m}$, and $\mathrm{HC}$ between 20 to $50 \mathrm{mD} / \mathrm{v} 3$. The MFZ is of HFU4 and ranked as a good reservoir quality rock. Seven MFZ's are observed in the studied wells (Fig. 9 to 12) track 2. The best HFZ is found in well OW2 (Fig. 10) with a thickness of $7.1 \mathrm{~m}$, average porosity, and permeability of $16.7 \%$ and $16 \mathrm{mD}$, respectively. The content of framework grain is high ( $79 \%$ on average), and the average content of quartz overgrowth is $(11.2 \%)$ and siderite cement ( $\leq 1.4 \%)$ and illite clay minerals $(\leq$ $0.7 \%$ ) are low (Table 3). Seven MFZ's contribute more than $26 \%$ flow and 58\% storage capacities, FU3.

\subsubsection{LFZ}

The grain size of the LFZ is mainly composed of lithofacies B (fine to medium sandstone) of class 2 of Lucia's classification. Fair petrophysical properties are observed, with porosity ranging from $10-18 \%$ and permeability from $20 \mathrm{mD}$ to $50 \mathrm{mD}$, respectively. The calculated Winland r35 pore throat size values range between 2 to $4 \mu \mathrm{m}$, FZI between 2 to $3 \mu \mathrm{m}$, and HC between 5 to $20 \mathrm{mD} / \mathrm{v} 3$. The LFZ is of HFU3 and ranked as a fair reservoir quality rock. Two LFZ's are observed in well OWI (Fig. 9 ) and OW4 (Fig. 12) track 2. The LFZ of well OW1 is bounded vertically at the top and bottom by HFZ. The LZF is interpreted to provide a lithofacies A and lithofacies B contact that allows fluid flow between the high flow zones ${ }^{24,68}$, implying that the HFZs are in communication. The LFZs identified to have the same average permeability of $10 \mathrm{mD}$ but differ in their average porosity values of $11.3 \%$ for well OW1 and $10.2 \%$ for well OW4, respectively. Comparison of calculated petrophysical properties between the two wells showed that OW4 has better pore throat size values ( $\mathrm{r} 35$ of $3.5 \mu \mathrm{m}$, an average $\mathrm{FZI}$ of $2.4 \mu \mathrm{m}$, and $\mathrm{HC}$ of $14 \mathrm{mD} / \mathrm{v} 3$ ) than that of well OW1 ( $\mathrm{r} 35$ of $2.3 \mu \mathrm{m}$, an average $\mathrm{FZI}$ of $2.1 \mu \mathrm{m}$, and $\mathrm{HC}$ of $6.0 \mathrm{mD} / \mathrm{v} 3$ ). The LZF is found in well OW2 (Fig. 10) with a thickness of $7.1 \mathrm{~m}$, average porosity, and permeability of $16.7 \%$ and $16 \mathrm{mD}$, respectively. According to ${ }^{1,69}$, pore throat radius is related to grain diameter, which explains why rocks of the same average permeability values may have different pore throat radius due to differences in pore volume. An average quartz framework grain of $74 \%$ and the average content of quartz overgrowth is (15.8\%), and siderite cement (1.35\%) and illite clay mineral( $0.9 \%)$ are presented for LFZ (Table 3). LFZ contributes about $15 \%$ flow and $20 \%$ storage capacities, FU3 (well OW4 in Fig. 12).

\subsubsection{TFZ}


The essential characteristic of TFZ is that it is predominantly composed of lithofacies $\mathrm{C}$ ( claystone, finely laminated with siltstone) and corresponds to class 3 of Lucia's classification. The petrophysical properties (porosity, permeability, Winland r35, FZI, and HC) of the TFZ are $\leq 1$, as shown in Table 2 . An average of $63 \%$ quartz framework grain with a slight increase (1.3 to $5.8 \%$ ) of carbonaceous material is indicated in this rock type. The highest amount of cement (quartz overgrowth, $18.8 \%$, siderite,6.2\%, pyrite, $2.6 \%$ ) and clay minerals (Kaolinite, $4.1 \%$ and illite, $2.6 \%$ ) are indicated in the TFZ samples (Table 3 ). The high amounts of cement and clay minerals ultimately fill the pores, block the pores, and constrict the sandstone's pore-throat, making the throat small, leading to poor reservoir properties observed in TFZ ${ }^{70}$. According to ${ }^{70}$, lower permeability values, as in our case $(\leq 1 \mathrm{mD})$, indicate that tiny pore throats play a dominant role in tight reservoirs. The pore throat is the primary physical property controlling the reservoir properties. Hence the lower the permeability, the smaller the pore throat radius.

TFZ has the most reduced reservoir property, and it is ranked as an impervious rock that acts as a barrier to flow, found in well OW3 (Fig. 11) and OW4 (Fig. 12), respectively. As a result, the TFZ has zero contribution to flow in both wells (OW3 and OW4) but has about $7 \%$ and $16 \%$ contributions to storage capacities (FU2) presented in Fig. 8 for both wells.

\section{Conclusions}

An integrated study has been used to delineate the sandstone reservoirs of an oil field in the Bredasdorp Basin into different potential flow zones, namely: high (HFZ), moderate (MFZ), low (LFZ), and tight (TFZ) flow zones. The petrophysical and mineralogical approach helped us understand the reservoir quality and assign flow zones to lithofacies.

The highest reservoir quality was assigned to lithofacies A (coarse and very coarse sandstone of Lucia's rock class I, which contains mostly megapores and is ranked as a very good reservoir rock. It is characterized by higher values for all petrophysical parameters (porosity generally between $18-22 \%$, permeability between $200 \mathrm{mD}$ to $1000 \mathrm{mD}, \mathrm{r} 35 \geq 10 \mu \mathrm{m}, \mathrm{FZI}=5-10 \mu \mathrm{m}$ and $\left.\mathrm{HC}=50-120 \mathrm{mD} / \mathrm{v}^{3}\right)$. The content of framework grain is high ( $80 \%$ on average), and the average content of quartz overgrowth is $(10 \%)$ and siderite cement $(\leq 1.3 \%)$, and illite $(\leq 0.5 \%)$. The HFZ is composed of HFU5, has a strong flow capacity, FU1 (60\%), and storage capacity of $42 \%$. The second best reservoir quality was the MFZ, composed of lithofacies A (coarse-grained sandstone) and B (fine to medium-grained sandstone), belonging to classes 1 and 2 of Lucia's Petrophysical classification. The MFZ's has good petrophysical properties with porosity ranging from $12-18 \%$ and permeability from $50 \mathrm{mD}$ to $200 \mathrm{mD}$. The pore throat size is good with calculated Winland $\mathrm{r} 35$ values range between 4 to $10 \mu \mathrm{m}$, FZI in the range between 3 to $5 \mu \mathrm{m}$, and $\mathrm{HC}$ between 20 to $50 \mathrm{mD} / \mathrm{v} 3$. The LFZ is mainly composed of lithofacies B (fine to medium sandstone) of class 2 of Lucia's classification with fair petrophysical properties. The LZF provides contact that allows fluid flow between HFZs and contributes about $15 \%$ flow and 20 $\%$ storage capacities, FU3. TFZ has the least reservoir quality, and it is predominantly composed of lithofacies C (claystone, finely laminated with siltstone) and corresponds to class 3 of Lucia's classification. The highest amount of cement (quartz overgrowth, $18.8 \%$, siderite, $6.2 \%$, pyrite, $2.6 \%$ ) and clay minerals (Kaolinite,4.1\% and illite, 2.6\%) are indicated in the TFZ samples. The high concentration of the cement and clay minerals ultimately fills the pores; it blocks the sandstone's pore-throat, making the throat small, leading to poor reservoir properties observed in TFZ intervals.

It can be concluded that petrophysical characterization of the sandstone reservoirs of the oil field has been achieved with good agreement to classify the sandstone and flow zones. This may indicate that the classification criteria can be confidently applied to other sandstone reservoirs in the basin.

\section{Declarations}

\subsection{Acknowledgment}

The authors are very grateful to the Petroleum Agency of South Africa, PASA, for providing the data and samples used in this study. Many thanks are also extended to Synergy LR company for giving us access to Interactive Petrophysics software (IP 4.7) used to analyse and process our data. The authors are grateful to the language editors for their contribution to improving the manuscript. Many thanks and appreciations are also extended to the Editor in Chief and anonymous reviewers.

\section{References}

1. Revil, A. \& Cathles lii, L. M. Permeability of shaly sands. Water Resources Research35,651-662(1999).

2. Lala, A. M. S. \& El-Sayed, N. A. Controls of pore throat radius distribution on permeability. Journal of Petroleum Science and Engineering157,941950(2017).

3. Spears, R. W. et al. Shale gas core analysis: strategies for normalizing between laboratories and a clear need for standard materials. in SPWLA 52nd Annual Logging Symposium (OnePetro, 2011).

4. Blount, A., McMullen, A., Durand, M., Croft, T. \& Driskill, B. Maintaining and reconstructing in-situ saturations: a comparison between whole core, sidewall core, and pressurized sidewall core in the Permian basin. in SPWLA 59th Annual Logging Symposium(OnePetro, 2018).

5. Ma, S. M. \& Amabeoku, M. Core analysis with emphasis on carbonate rocks-quality assurance and control for accuracy and representativeness. Interpretation3,SA91-SA106(2015).

6. Opuwari, M. Petrophysical evaluation of the Albian age gas bearing sandstone reservoirs of the OM field, Orange basin, South Africa (University of the Western Cape, 2010).

7. Male, F. \& Duncan, I. J. Lessons for machine learning from the analysis of porosity-permeability transforms for carbonate reservoirs. Journal of Petroleum Science and Engineering187,106825(2020). 
8. Nabawy, B. S. Impacts of the pore-and petro-fabrics on porosity exponent and lithology factor of Archie's equation for carbonate rocks. Journal of African Earth Sciences108,101-114(2015).

9. Radwan, A. E., Nabawy, B. S., Kassem, A. A. \& Hussein, W. S. Implementation of rock typing on waterflooding process during secondary recovery in oil reservoirs: A case study, El Morgan Oil Field, Gulf of Suez, Egypt.Natural Resources Research30,1667-1696(2021).

10. El Sharawy, M. S. \& Nabawy, B. S. Integration of electrofacies and hydraulic flow units to delineate reservoir quality in uncored reservoirs: A case study, Nubia Sandstone Reservoir, Gulf of Suez, Egypt.Natural Resources Research28,1587-1608(2019).

11. Tiab, D., Donaldson, E. \& Petrophysics Theory and Practice of Measuring Reservoir Rock and Fluid Transport Properties, Gulf Publ.Co., Houston, Texas205-220(1996).

12. Daraei, M., Bayet-Goll, A. \& Ansari, M. An integrated reservoir zonation in sequence stratigraphic framework: A case from the Dezful Embayment, Zagros, Iran. Journal of Petroleum Science and Engineering154,389-404(2017).

13. Opuwari, M., Bialik, O. M., Taha, N. \& Waldmann, N. D. The role of detrital components in the petrophysical parameters of Paleogene calcareousdominated hemipelagic deposits. Arabian Journal of Geosciences14,1-13(2021).

14. Archie, G. E. Introduction to petrophysics of reservoir rocks.AAPG bulletin34,943-961(1950).

15. Hearn, C. L., Ebanks, W., Tye, R. S. \& Ranganathan, V. Geological factors influencing reservoir performance of the Hartzog Draw Field, Wyoming.Journal of Petroleum Technology36,1335-1344(1984).

16. Martin, A. J., Solomon, S. T. \& Hartmann, D. J. Characterization of petrophysical flow units in carbonate reservoirs.AAPG bulletin81,734-759(1997).

17. Magoba, M. \& Opuwari, M. Petrophysical interpretation and fluid substitution modelling of the upper shallow marine sandstone reservoirs in the Bredasdorp Basin, offshore South Africa.Journal of Petroleum Exploration and Production Technology10,783-803(2020).

18. Rahimpour-Bonab, H. A procedure for appraisal of a hydrocarbon reservoir continuity and quantification of its heterogeneity. Journal of Petroleum Science and Engineering58,1-12(2007).

19. Rahimpour-Bonab, H., Asadi-Eskandari, A. \& Sonei, A. Control of Permian-Triassic Boundary over reservoir characteristics of South Pars Gas Field. (2009).

20. Samakinde, C., Opuwari, M. \& van Bever Donker, J. M. The effects of clay diagenesis on petrophysical properties of the lower Cretaceous sandstone reservoirs, Orange Basin, South Africa.South African Journal of Geology 2016119,187-202(2016).

21. Baron, M. et al. Evolution of hydrocarbon migration style in a fractured reservoir deduced from fluid inclusion data, Clair Field, west of Shetland, UK.Marine and Petroleum Geology25,153-172(2008).

22. Cerepi, A., Barde, J. P. \& Labat, N. High-resolution characterization and integrated study of a reservoir formation: the danian carbonate platform in the Aquitaine Basin (France). Marine and Petroleum Geology20,1161-1183(2003).

23. Tavakoli, V., Rahimpour-Bonab, H. \& Esrafili-Dizaji, B. Diagenetic controlled reservoir quality of South Pars gas field, an integrated approach.Comptes Rendus Geoscience343,55-71(2011).

24. Opuwari, M., Mohammed, S. \& Ile, C. Determination of Reservoir Flow Units from Core Data: A Case Study of the Lower Cretaceous Sandstone Reservoirs, Western Bredasdorp Basin Offshore in South Africa.Natural Resources Research30,411-430(2021).

25. Opuwari, M. \& Dominick, N. Sandstone reservoir zonation of the north-western Bredasdorp Basin South Africa using core data.Journal of Applied Geophysics104425 (2021).

26. Opuwari, M., Magoba, M., Dominick, N. \& Waldmann, N. Delineation of Sandstone Reservoir Flow Zones in the Central Bredasdorp Basin, South Africa, Using Core Samples. Natural Resources Research1-22(2021).

27. Davies, C. P. Unusual biomarker maturation ratio changes through the oil window, a consequence of varied thermal history. Organic geochemistry27,537560(1997).

28. Burden, P. L. \& Davies, C. P. South Africa offshore EXP. II: Oribi field is South Africa's first offshore crude oil production. Oil \& gas journa/95,63-65(1997).

29. Elliott, T. et al. 1995. Sequence Stratigraphy in Offshore South African Divergent Basins. An Atlas on Exploration for Cretaceous Lowstand Traps by Soekor (Pty) Ltd. AAPG Studies in Geology Series no. 41. vii + 184 pp.(very large format: 11 imes\$ 24 inches, 28 \$imes $\$ 61 \mathrm{~cm})$. Tulsa: American Association of Petroleum Geologists. Price US 59.00 for AAPG members); paperback. ISBN 089181049 8. Geological Magazine 134, 121-142 (1997).

30. McMillan, I. K., Brink, G. I., Broad, D. S. \& Maier, J. J. Late Mesozoic sedimentary basins off the south coast of South Africa. in Sedimentary Basins of the World vol. 3319-376(Elsevier, 1997).

31. Megner-Allogo, A. C. Sedimentology and stratigraphy of deep-water reservoirs in the 9A to $14 A$ Sequences of the central Bredasdorp Basin, offshore South Africa (Stellenbosch University, Stellenbosch, 2006).

32. Africa, P. A. S. Petroleum exploration information and opportunities.Petroleum Agency South Africa Report44p (2003).

33. Brown, L. F. Jr et al. SG41: Sequence Stratigraphy in Offshore South African Divergent Basins-Front Matter(1995).

34. Hälbich, I. W., Fitch, F. J. \& Miller, J. A. Dating the Cape orogeny. in Geodynamics of the Cape Fold Belt(1983).

35. Dingle, R. V., Siesser, W. G. \& Newton, A. R. Mesozoic and Tertiary geology of southern Africa (AA Balkema, 1983).

36. Broad, D. S., Jungslager, E. H. A., McLachlan, I. R. \& Roux, J. Offshore mesozoic basins. The Geology of South Africa. Geological Society of South Africa,Johannesburg/Council for Geoscience, Pretoria553,571(2006).

37. Jungslager, E. H. Petroleum habitats of the Atlantic margin of South Africa.Geological Society, London, Special Publications153,153-168(1999).

38. Smith, R. M. Alluvial paleosols and pedofacies sequences in the Permian Lower Beaufort of the southwestern Karoo Basin, South Africa. Journal of Sedimentary Research60,258-276(1990).

39. Jain, A. K. Data clustering: 50 years beyond K-means. Pattern recognition letters31,651-666(2010). 
40. Compan, A. L., Bodstein, G. C. \& Couto, P. A relative permeability rock-typing methodology with a clustering method combined with a heuristic optimization procedure.SPE Journal21,1899-1915(2016).

41. Ahr, W. M. Geology of carbonate reservoirs: the identification, description and characterization of hydrocarbon reservoirs in carbonate rocks (John Wiley \& Sons, 2011).

42. Ebanks, W. J. Jr Flow unit concept-integrated approach to reservoir description for engineering projects.AAPG (Am. Assoc. Pet. Geol.) Bull.;(United States)71, (1987).

43. Lucia, F. J. Petrophysical parameters estimated from visual descriptions of carbonate rocks: a field classification of carbonate pore space.Journal of petroleum technology35,629-637(1983).

44. Lucia, F. J. Rock-fabric/petrophysical classification of carbonate pore space for reservoir characterization.AAPG bulletin79,1275-1300(1995).

45. Amaefule, J. O., Altunbay, M., Tiab, D., Kersey, D. G. \& Keelan, D. K. Enhanced reservoir description: using core and log data to identify hydraulic (flow) units and predict permeability in uncored intervals/wells. in SPE annual technical conference and exhibition (OnePetro, 1993).

46. Abbaszadeh, M., Fujii, H. \& Fujimoto, F. Permeability prediction by hydraulic flow units-theory and applications, SPE 30158. in Proceedings of SPE Petrovietnam Conference(1995).

47. Perez, H. H., Datta-Gupta, A. \& Mishra, S. The role of electrofacies, lithofacies, and hydraulic flow units in permeability predictions from well logs: a comparative analysis using classification trees. in SPE Annual Technical Conference and Exhibition(OnePetro, 2003).

48. Kadkhodaie-llkhchi, R., Rezaee, R., Moussavi-Harami, R. \& Kadkhodaie-llkhchi, A. Analysis of the reservoir electrofacies in the framework of hydraulic flow units in the Whicher Range Field, Perth Basin, Western Australia. Journal of Petroleum Science and Engineering111,106-120(2013).

49. Nabawy, B. S. \& Al-Azazi, N. A. Reservoir zonation and discrimination using the routine core analyses data: the upper Jurassic Sab'atayn sandstones as a case study, Sab'atayn basin, Yemen.Arabian Journal of Geosciences8,5511-5530(2015).

50. Winland, H. D. Oil accumulation in response to pore size changes, Weyburn field, Saskatchewan.Amoco Production Research Report No.F72-G25 (1972).

51. Kolodzie, S. Analysis of pore throat size and use of the Waxman-Smits equation to determine OOIP in Spindle Field, Colorado. in SPE annual technical conference and exhibition (OnePetro, 1980).

52. Porras, J. C., Barbato, R. \& Khazen, L. Reservoir flow units: A comparison between three different models in the Santa Barbara and Pirital fields, North Monagas Area, Eastern Venezuela Basin. in Latin American and Caribbean petroleum engineering conference(OnePetro, 1999).

53. Palabiran, M., Sesilia, N. \& Akbar, M. N. A. An Analysis of Rock Typing Methods in Carbonate Rocks for Better Carbonate Reservoir Characterization: a Case Study of Minahaki Carbonate Formation, Banggai Sula Basin, Central Sulawesi. in 41th Scientific Annual Meeting of Indonesian Association of Geophysicists (Pit Hagi) Lampung,(Aip Conference Proceedings)(2016).

54. Abuamarah, B. A. \& Nabawy, B. S. A proposed classification for the reservoir quality assessment of hydrocarbon-bearing sandstone and carbonate reservoirs: A correlative study based on different assessment petrophysical procedures. Journal of Natural Gas Science and Engineering88,103807(2021)

55. Opuwari, M., Kaushalendra, B. T. \& Momoh, A. Sandstone reservoir zonation using conventional core data: A case study of lower cretaceous sandstones, Orange Basin, South Africa. Journal of African Earth Sciences153,54-66(2019).

56. Leverett, M. Capillary behavior in porous solids. Transactions of the AIME142,152-169(1941).

57. Permadi, P. \& Susilo, A. An Investigation of the Interrelation Among Pore Throat, Surface Area, Permeability, and NMR Log Data. Final Study Report of ITB(2004).

58. Scheidegger, A. E. On the theory of flow of miscible phases in porous media.International Union of Geodesy and Geophysics in Toronto(1957).

59. Gunter, G. W., Finneran, J. M., Hartmann, D. J. \& Miller, J. D. Early determination of reservoir flow units using an integrated petrophysical method. in SPE annual technical conference and exhibition (OnePetro, 1997).

60. Slatt, R. M. \& Hopkins, G. L. Scaling geologic reservoir description to engineering needs. Journal of Petroleum Technology42,202-210(1990).

61. Pranter, M. J., Hurley, N. F. \& Davis, T. L. Sequence-stratigraphic, petrophysical, and multicomponent seismic analysis of a shelf-margin reservoir (San Andres Formation (Permian), Vacuum field, New Mexico, United States, 2004).

62. Craig, F. F. The Reservoir Engineering Aspects of Waterflooding: Society of Petroleum Engineers, Monograph volume 3 of the Henry L. Doherty Series, Dallas, TX(1993)

63. Yarmohammadi, S., Kadkhodaie-llkhchi, A., Rahimpour-Bonab, H. \& Shirzadi, A. Seismic reservoir characterization of a deep water sandstone reservoir using hydraulic and electrical flow units: a case study from the Shah Deniz gas field, the South Caspian Sea.Journal of Petroleum Science and Engineering $118,52-60(2014)$.

64. Lai, J. et al. A review on pore structure characterization in tight sandstones. Earth-Science Reviews177,436-457(2018).

65. Worden, R. H. \& Morad, S. Clay minerals in sandstones: controls on formation, distribution and evolution.Clay mineral cements in sandstones1-41(1999).

66. Worden, R. H. \& Burley, S. D. Sandstone diagenesis: Recent and ancient (Blackwell, 2003).

67. Kamal, M. S., Mahmoud, M., Hanfi, M., Elkatatny, S. \& Hussein, I. Clay minerals damage quantification in sandstone rocks using core flooding and NMR. Journal of Petroleum Exploration and Production Technology9,593-603(2019).

68. Larue, D. K. \& Legarre, H. Flow units, connectivity, and reservoir characterization in a wave-dominated deltaic reservoir: Meren reservoir, Nigeria.AAPG bulletin88,303-324(2004).

69. Lala, A. M. S. \& Lala, H. M. S. Study on the improving method for gas production prediction in tight clastic reservoir.Arabian Journal of Geosciences10,18(2017). 
70. Wang, W. et al. Pore-throat characteristics of tight sandstone reservoirs composed of gravity flow sediments: yingcheng Formation, Longfengshan sag, China. Journal of Petroleum Science and Engineering171,646-661(2018).

\section{Figures}

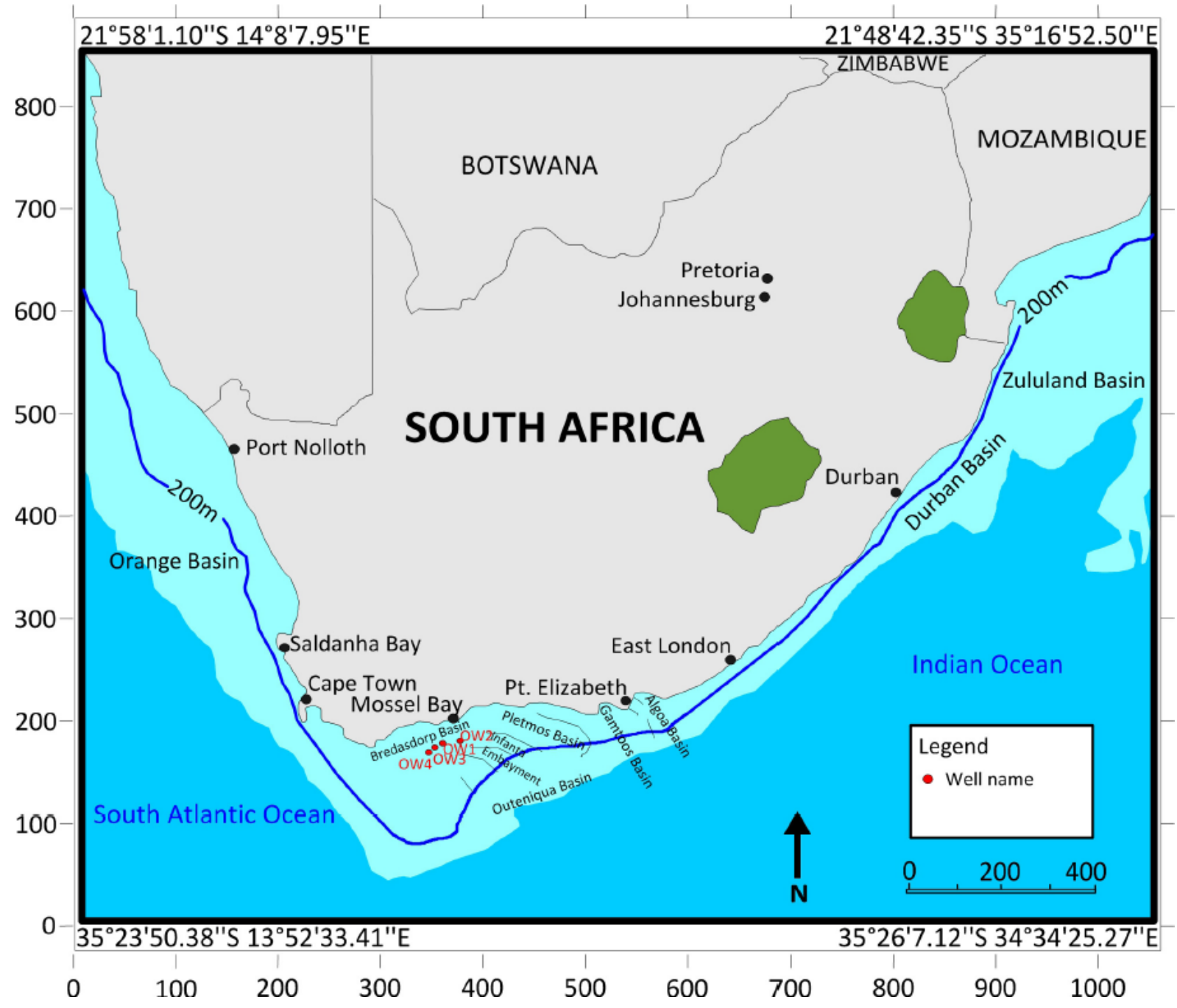

Figure 1

Location map showing the study area, including the well locations offshore of South Africa 


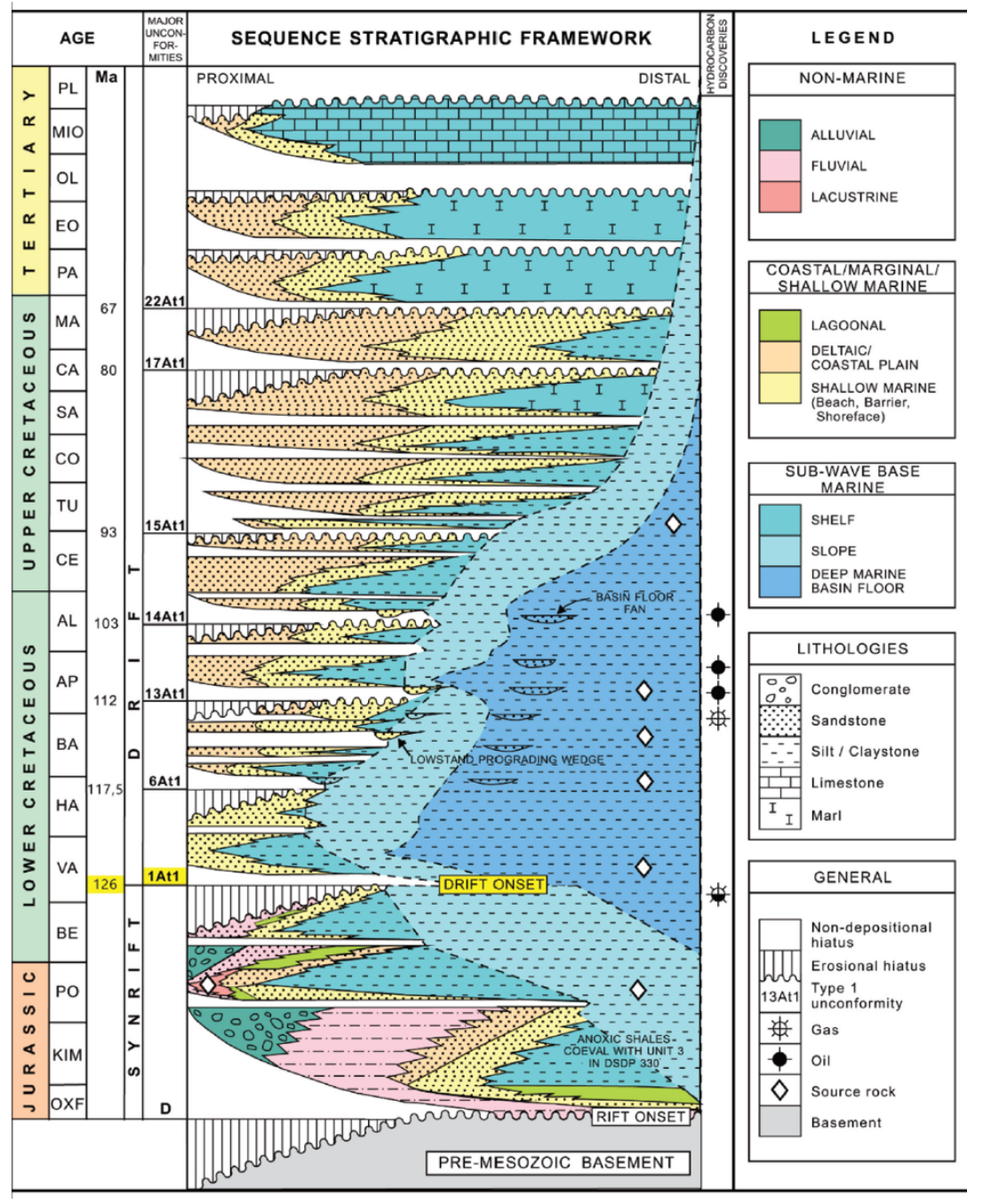

\section{Figure 2}

Stratigraphic nomenclature of sedimentary successions in South Africa's Offshore Basins 29,33 

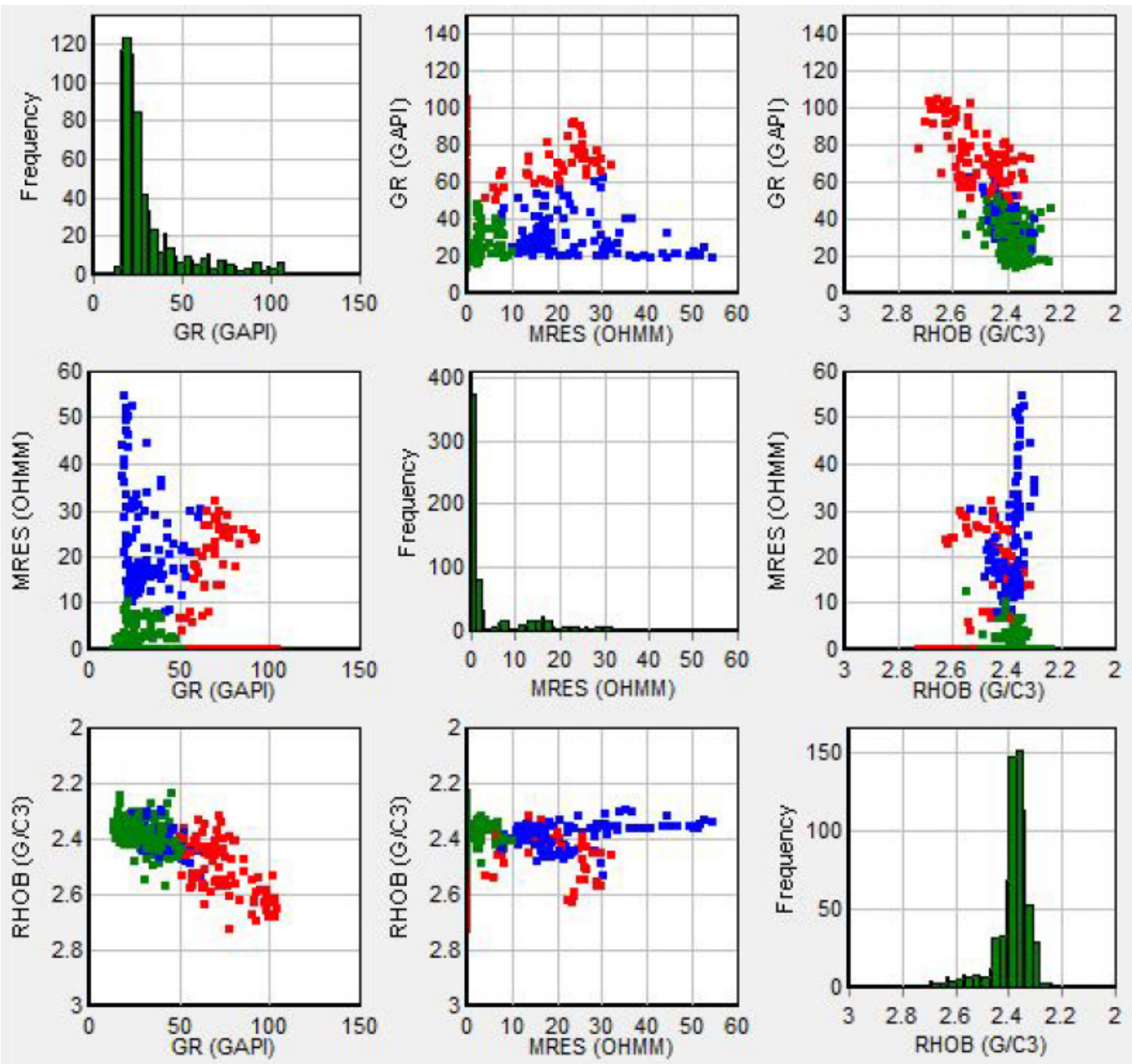

Figure 3

Cluster analysis showing lithofacies identified in the wells from well logs. 


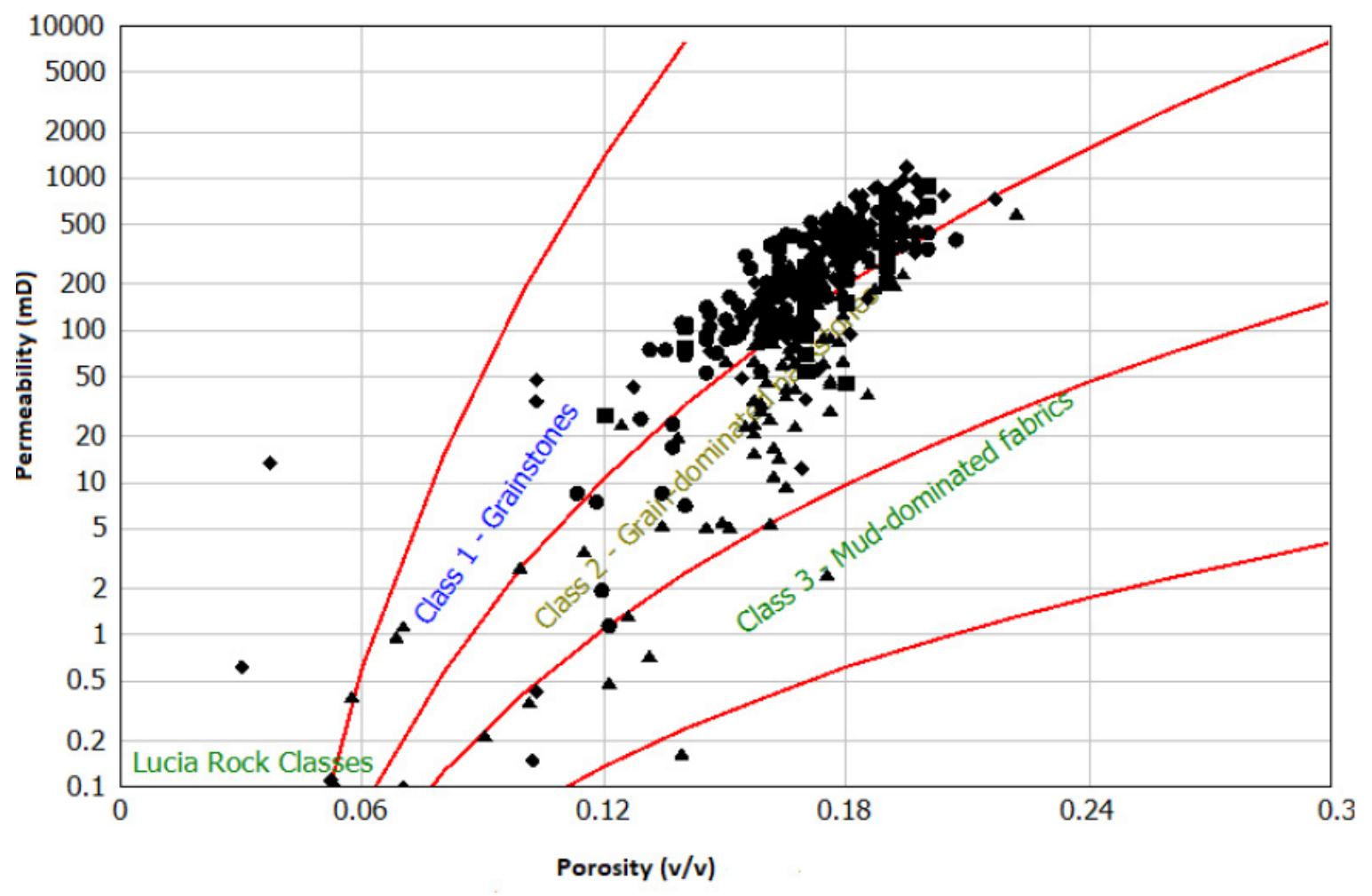

Figure 4

Lucia's Petrophysical rock classification showing three classes of rock. 
FZI Hydraulic Flow Units
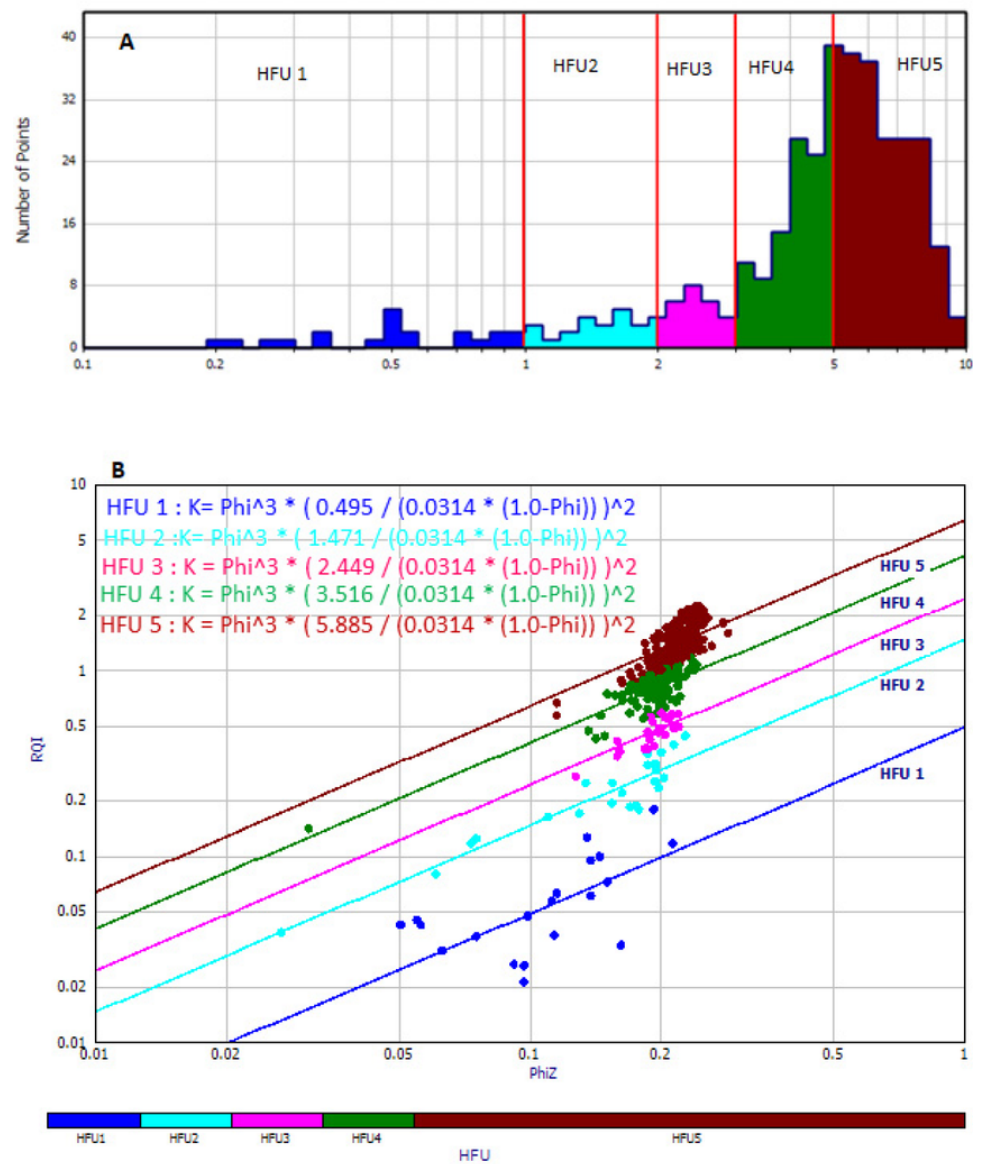

\section{Figure 5}

Results of flow zone indicator (a) Histogram of vertical boundary lines(red) showing boundaries of flow units (b) log-log plot of RQI versus normalized porosity (Phiz) showing five distinct flow units and respective relationships for the determination of permeability(K) from hydraulic flow unit.
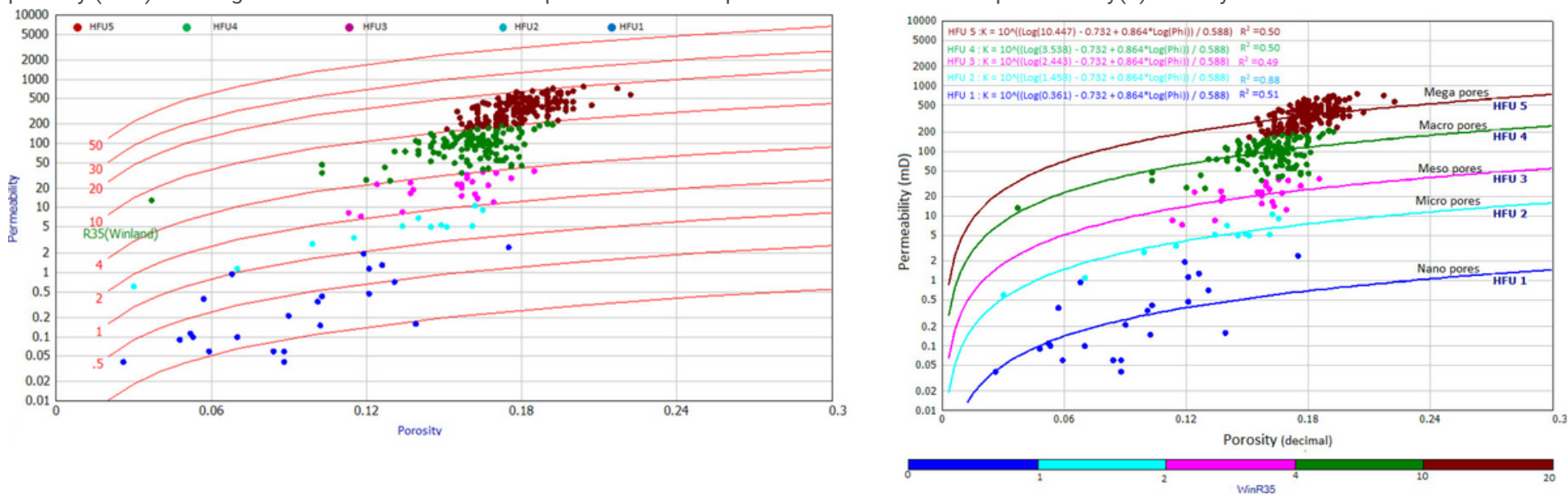

Figure 6

a: Winland r35 pore throat radius for the identification of rock types, showing five different rock types from HFU 1 to HFU5 b: Results of Winland r35 pore throat radius showing five different equations for rock types 
(KIP)^0.5 / Hydraulic Conductivity

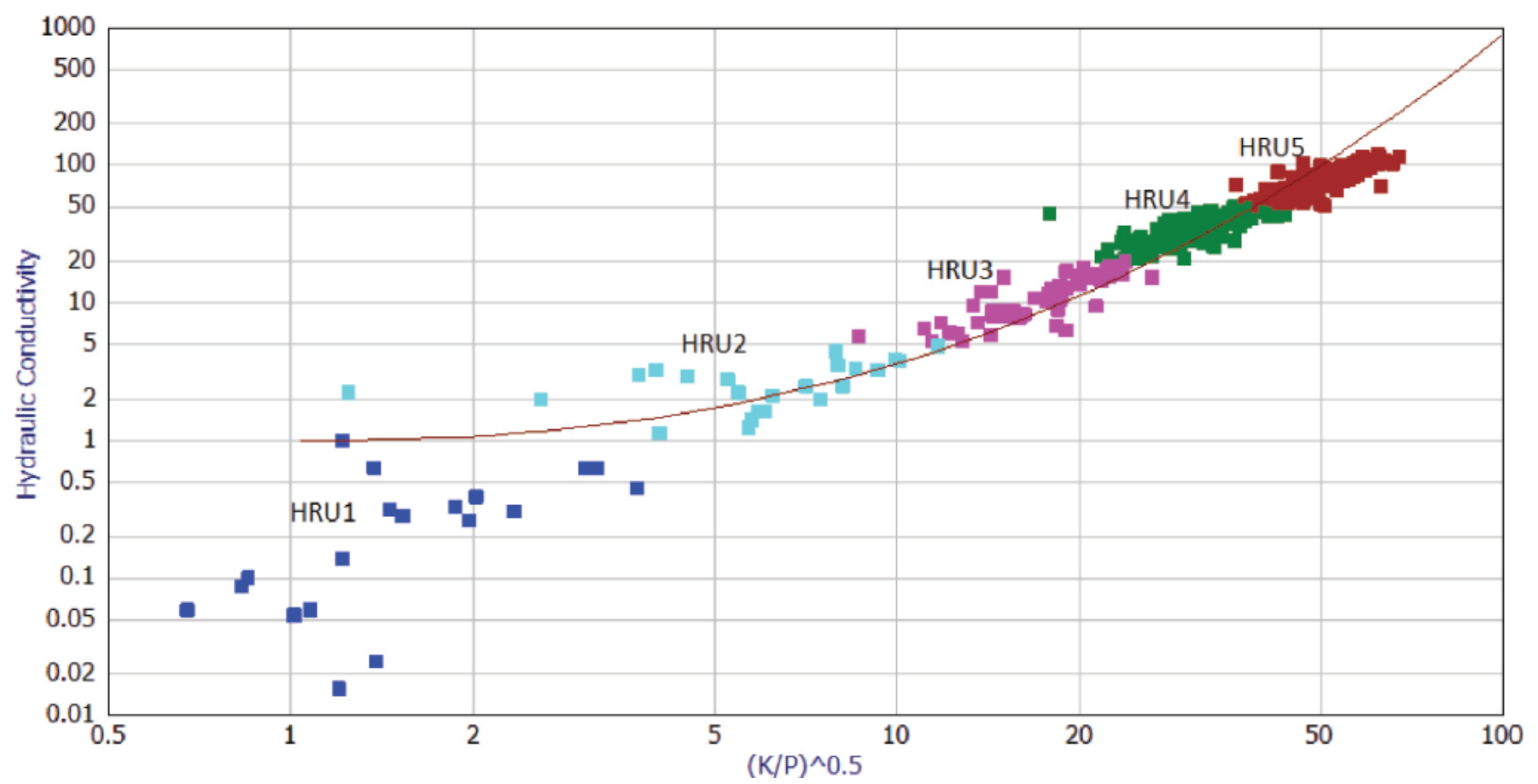

Figure 7

Cross plot of hydraulic conductivity against K/P indicating hydraulic reservoir units encountered in the wells.

\section{CumPH / CumKH}

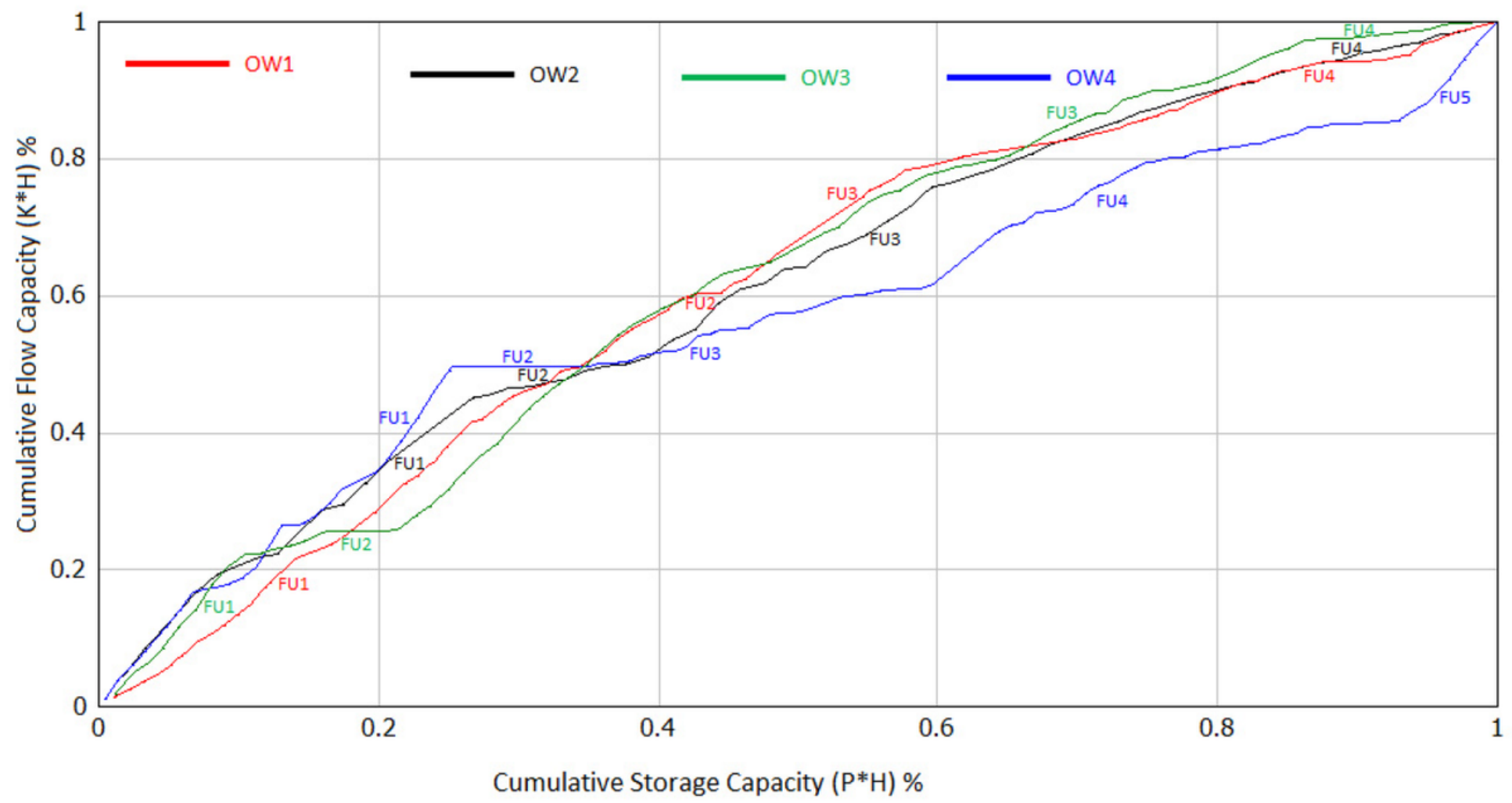

Figure 8

Stratigraphic modified Lorenz plots (SMPLs) for the studied wells showing different flow units (FUs)

Page 16/19 


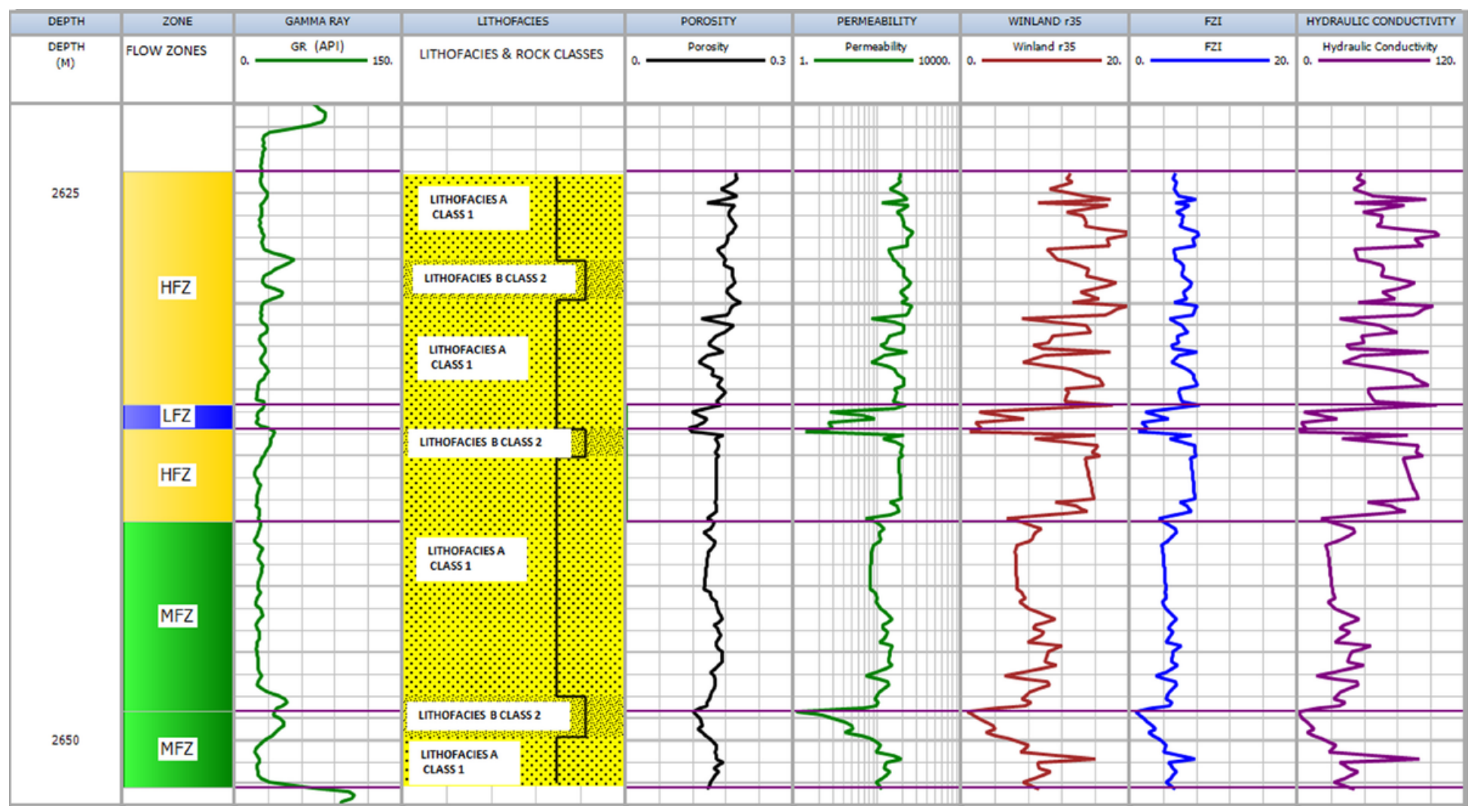

Figure 9

Shows the results for well OW1. Track 1 shows the measured depth. Displayed in tracks $2-9$ are flow zones, Gamma ray log, lithofacies, porosity, permeability, Winand r35, Flow zone indicator, and hydraulic conductivity.

ow2

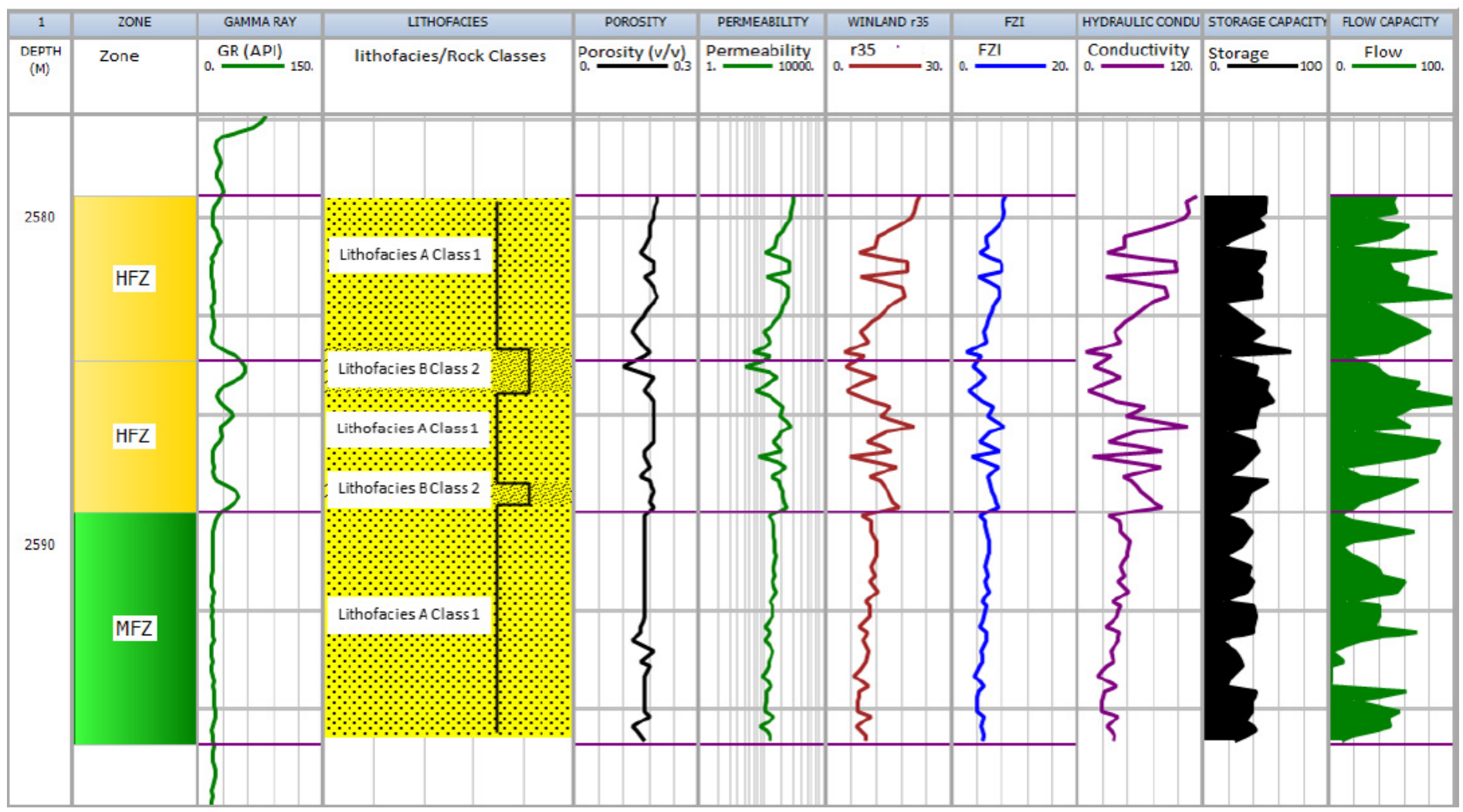

Figure 10 
Shows the results for well OW2. Track 1 shows the measured depth. Displayed in tracks $2-9$ are flow zones, Gamma ray log, lithofacies, porosity, permeability, Winand r35, Flow zone indicator, and hydraulic conductivity.

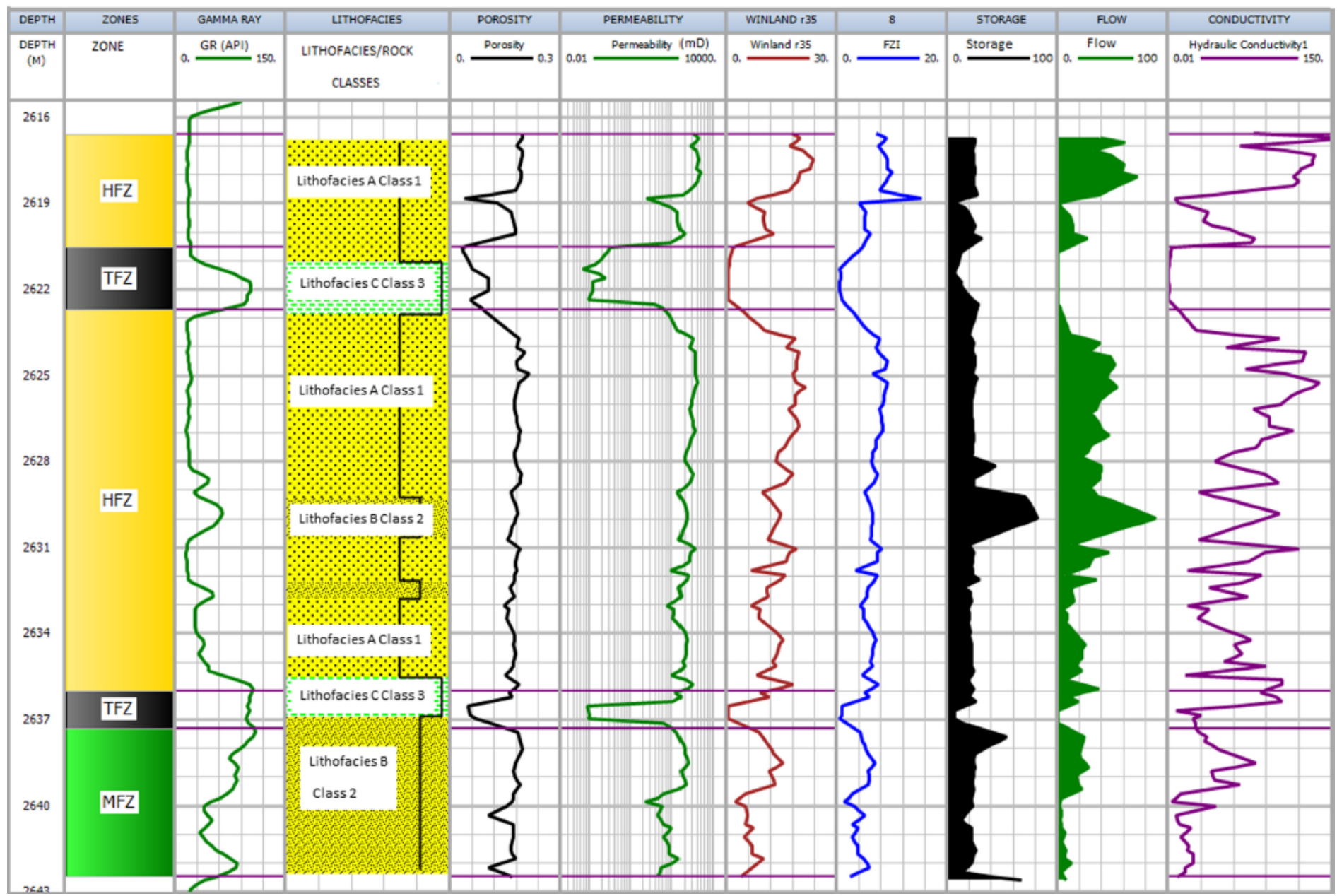

Figure 11

Shows the results for well OW3. Track 1 shows the measured depth. Displayed in tracks $2-9$ are flow zones, Gamma ray log, lithofacies, porosity, permeability, Winand r35, Flow zone indicator, and hydraulic conductivity. 
OW4

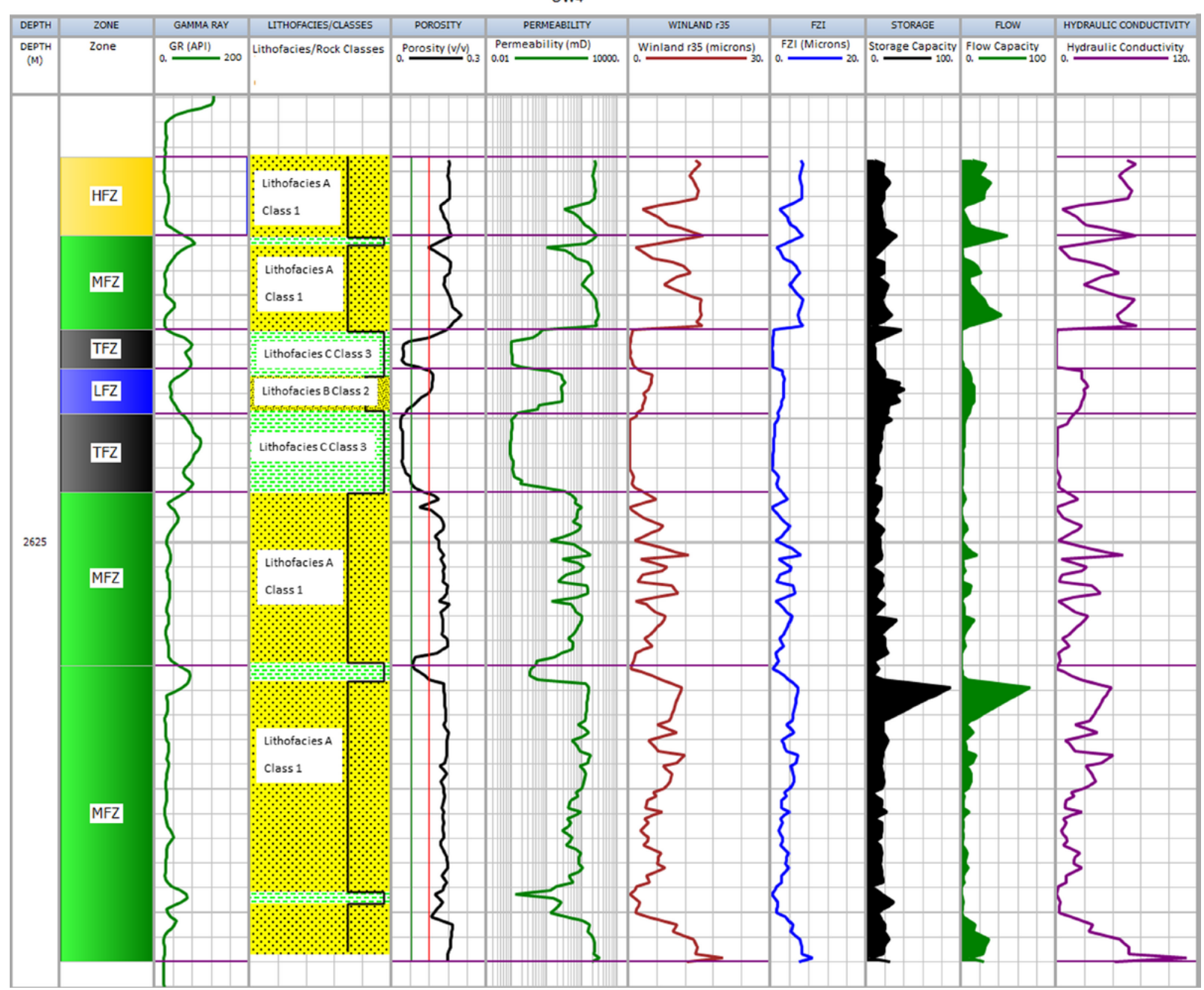

Figure 12

Shows the results for well OW4. Track 1 shows the measured depth. Displayed in tracks $2-9$ are flow zones, Gamma ray log, lithofacies, porosity, permeability, Winand r35, Flow zone indicator, and hydraulic conductivity. 